\title{
Recent Study of Ground Water Quality of Sambalpur Municipal Corporation, Odisha, India
}

\author{
D.K Sahu *, Binita Sahu ** \\ *(Department of Chemistry, Black Diamond College of Engineering \& Technology, Odisha, India \\ ** (Department of Chemistry, Black Diamond College of Engineering \& Technology, Odisha, India
}

\begin{abstract}
Thirty three different locations like Industrial, Educational, Cultural, Business area in Sambalpur Municipal Corporation of Odisha, India, indicate pressure on unconfined aquifer condition at a depth varying from 0.6 to $40 \mathrm{~m}$ below a thin soil horizon. The ground water sample collected from good numbers of bore wells during premonsoon period of 2016 were analyzed for different physico-chemical parameter ( hardness, Calcium, Sodium, Potassium, Magnesium, Fluoride, sulphate, Carbonate, Alkalinity, COD, DO, etc.) including their suitability for various process. The qualities of ground water sample of the study area indicate the dominance of host rocks as the controlling factor for chemical composition. Analysis of results showed that the ground water is fit for drinking as pert standard prescribed by World Health Organization.
\end{abstract}

Keywords: Amphibolites, Chemical oxygen demand, Dissolved oxygen, Hardness of water, Petrographic analysis, Physico-chemical parameters, Predominant rock, Sericitization.

\section{INTRODUCTION}

The importance of resources evaluation for ground water has increased many folds in the last three decades because of rapid industrialization and urbanization as over dependent on ground water. The increasing human interaction with nature has severely affected by the consumable surface water regulating the ground water as a new source. It is no secret that most of rural areas of India even towns as cities do not have access the safe drinking water, although the country has to made spectacular program in certain areas of sciences and technology during the last five decades after independence. Sambalpur Municipal Corporation is a new corporation declared by government in the year 2014. It is mainly an educational town Burla, having Technical University, Sambalpur University, Medical college and research, Mahanadi Coal Field's Computer Office, etc. Hirakud is an old Industrial town with Hindalco Industries, Hira Cables, Blue Fox, etc, developed after the construction of largest Hirakud Dam in 1954, this Sambalpur and Hirakud Cultural town since 1000 year the heart place of Western Odisha having population more than $5,00,000$. The city $\left(20^{\circ} 28^{\prime}-\right.$ $21031^{\prime} \mathrm{N}$ and $830-83055^{\prime} \mathrm{E}$ ) has a typical monsoon climate and main drainage system is controlled by the river Mahanadi with an undulated topography. The area in marled by a thin soil profile of primarily sandy soil.The predominate rock type of the area is granite type. Suggest to multi component body [1]. The secondary features due to the deformation weathering and alteration of parent rocks are main aquifer forming factors besides the primary structural and physico-chemical features.

\section{MATERIAS AND METHODS}

Thirty three ground water samples in triplicates were collected during the pre-monsoon period of 2016 from the bore wells in one liter precleaned polyethelylene bottles as per standard procedures [2]. The locations of sampling sites in the areas are given namely (see Figure-1). Temperature, $\mathrm{pH}$, conductance, dissolved oxygen and dissolved $\mathrm{CO}_{2}$ samples were collected and determined on the spot and other physico-chemical parameters were estimated [3], [4]. The major rock types were demarcated and petro graphic analysis was done with help of point counter. 
Table 1.A.: Physico-chemical parameters of different bore wells.

\begin{tabular}{|c|c|c|c|c|c|c|c|c|}
\hline $\begin{array}{l}\text { Bore well number \& } \\
\text { location }\end{array}$ & $\begin{array}{l}\mathrm{pH} \\
\mathrm{moles} / \mathrm{L}\end{array}$ & $\begin{array}{l}\mathrm{EC} \\
\mu \mathrm{v} / \mathrm{cm}\end{array}$ & $\begin{array}{l}\text { Temp } \\
{ }^{\circ} \mathrm{C}\end{array}$ & $\begin{array}{l}\text { TDS } \\
\text { ppm }\end{array}$ & $\begin{array}{l}\text { TH } \\
\text { ppm }\end{array}$ & $\begin{array}{l}\text { TA } \\
\mathrm{ppm}\end{array}$ & $\begin{array}{l}\mathrm{DO} \\
\mathrm{ppm}\end{array}$ & $\begin{array}{l}\text { COD } \\
\text { ppm }\end{array}$ \\
\hline 1. Village-1 & 7.62 & 385 & 31.0 & 298 & 233 & 99 & 3.8 & 27.18 \\
\hline 2. Township-1 & 7.75 & 888 & 31.9 & 411 & 411 & 121 & 2.4 & 31.11 \\
\hline 3.Vimsar Medical College & 7.41 & 896 & 33.1 & 455 & 455 & 111 & 2.2 & 28.7 \\
\hline 4. Market & 7.81 & 705 & 32.3 & 298 & 298 & 111 & 3.1 & 29.6 \\
\hline 5. Township-2 & 7.70 & 828 & 33.2 & 388 & 388 & 136 & 4.6 & 41.3 \\
\hline 6. Sambalpur University & 7.91 & 721 & 32.8 & 121 & 121 & 88 & 4.8 & 38.7 \\
\hline 7. Katapali & 7.66 & 411 & 30.9 & 321 & 321 & 190 & 3.9 & 42.2 \\
\hline 8. Golgunda & 7.91 & 427 & 30.8 & 375 & 375 & 107 & 2.9 & 29.7 \\
\hline 9. Village-2 & 8.02 & 626 & 31.7 & 611 & 611 & 109 & 4.1 & 24.7 \\
\hline 10. VSSUT & 7.94 & 640 & 34.2 & 421 & 421 & 100 & 4.2 & 18.8 \\
\hline 11. MCL Office & 7.69 & 711 & 36.1 & 555 & 555 & 99 & 4.0 & 35.2 \\
\hline 12. HINDALCO & 7.88 & 999 & 29.9 & 281 & 281 & 68 & 4.5 & 31.7 \\
\hline 13. Blue Fox Industry & 7.38 & 712 & 30.5 & 79 & 66 & 71 & 3.8 & 34.4 \\
\hline 14. Village-3 & 8.21 & 1096 & 31.2 & 211 & 102 & 88 & 2.4 & 38.8 \\
\hline 15. Remed & 7.81 & 921 & 33.3 & 311 & 188 & 93 & 2.3 & 42.2 \\
\hline 16. Bareipali & 7.77 & 412 & 32.1 & 618 & 300 & 126 & 3.7 & 41.1 \\
\hline 17. Airport & 8.31 & 1235 & 34.6 & 325 & 101 & 91 & 4.1 & 39.1 \\
\hline 18. Village-4 & 7.21 & 918 & 35.1 & 428 & 161 & 121 & 4.0 & 19.2 \\
\hline 19. Government. Hospital & 7.90 & 1301 & 32.3 & 602 & 189 & 111 & 3.8 & 22.2 \\
\hline 20. Tangerpali & 7.66 & 428 & 31.9 & 598 & 201 & 100 & 2.9 & 40.6 \\
\hline 21. GM university & 8.40 & 511 & 32.9 & 611 & 222 & 106 & 4.2 & 35.7 \\
\hline 22. Gopalmal & 7.31 & 611 & 30.8 & 583 & 188 & 101 & 3.8 & 39.1 \\
\hline 23. Danipali & 8.61 & 728 & 31.0 & 621 & 206 & 99 & 3.8 & 40.4 \\
\hline 24. Durgapali & 8.57 & 915 & 32.0 & 310 & 108 & 98 & 4.1 & 32.2 \\
\hline 25. Budharaja & 7.91 & 710 & 30.8 & 421 & 133 & 81 & 4.2 & 28.4 \\
\hline 26. New Township & 7.92 & 428 & 32.3 & 619 & 196 & 71 & 4.1 & 99.9 \\
\hline 27. Modipara & 7.69 & 555 & 32.4 & 311 & 109 & 61 & 4.61 & 31.1 \\
\hline 28. Police Hospital & 7.88 & 729 & 30.8 & 199 & 98 & 51 & 4.02 & 11.8 \\
\hline 29. Daleipara & 7.90 & 1029 & 34.1 & 218 & 107 & 61 & 4.3 & 28.8 \\
\hline 30. Brooxhill & 7.61 & 621 & 33.3 & 701 & 206 & 99 & 4.2 & 39.9 \\
\hline 31. Charbhati & 7.66 & 778 & 32.6 & 311 & 109 & 69 & 4.1 & 34.6 \\
\hline 32. Binakhandi & 7.67 & 926 & 31.0 & 429 & 211 & 90 & 4.11 & 33.3 \\
\hline 33. Maneswar & 7.66 & 710 & 32.8 & 512 & 166 & 100 & 4.21 & 31.01 \\
\hline
\end{tabular}

Table 1.B.: Physico-chemical parameters of different bore wells.

\begin{tabular}{|l|l|l|l|l|l|l|l|l|l|l|}
\hline $\begin{array}{l}\text { Bore well number \& } \\
\text { location }\end{array}$ & $\begin{array}{l}\mathrm{Ca}^{2+} \\
\mathrm{ppm}\end{array}$ & $\begin{array}{l}\mathrm{Mg}^{2+} \\
\mathrm{ppm}\end{array}$ & $\begin{array}{l}\mathrm{Na}^{+} \\
\mathrm{ppm}\end{array}$ & $\begin{array}{l}\mathrm{K}^{+} \\
\mathrm{ppm}\end{array}$ & $\begin{array}{l}\mathrm{Cl}^{-} \\
\mathrm{ppm}\end{array}$ & $\begin{array}{l}\mathrm{SO}_{4}^{2-} \\
\mathrm{ppm}\end{array}$ & $\begin{array}{l}\mathrm{F}^{-} \\
\mathrm{ppm}\end{array}$ & $\begin{array}{l}\mathrm{CO}_{3}^{2-} \\
\mathrm{ppm}\end{array}$ & $\begin{array}{l}\mathrm{HCO}_{3}^{-} \\
\mathrm{ppm}\end{array}$ & $\begin{array}{l}\mathrm{CO}_{2} \\
\mathrm{ppm}\end{array}$ \\
\hline 1. Village-1 & 7.9 & 8.2 & 11.2 & 11.9 & 28 & 0.8 & 1.01 & 3 & 40 & 12 \\
\hline 2. Township-1 & 11.2 & 8.1 & 18.6 & 14.6 & 64 & 2.8 & 1.2 & 18 & 46 & 11 \\
\hline $\begin{array}{l}\text { 3.Vimsar Medical } \\
\text { College }\end{array}$ & 8.8 & 7.1 & 6.4 & 16.7 & 61 & 0.9 & 0.9 & 22 & 28 & 18 \\
\hline 4. Market & 18.7 & 6.3 & 18.6 & 15.4 & 80 & 1.1 & 0.6 & 35 & 111 & 14 \\
\hline 5. Township-2 & 10.6 & 5.8 & 18.9 & 9.9 & 18 & 2.6 & 0.71 & 0 & 96 & 9 \\
\hline $\begin{array}{l}\text { 6.Sambalpur } \\
\text { University }\end{array}$ & 19.2 & 2.6 & 3.8 & 11.8 & 99 & 0.7 & 0.88 & 0 & 215 & 11 \\
\hline 7. Katapali & 9.9 & 7.2 & 28.6 & 17.1 & 103 & 3.4 & 0.88 & 7 & 111 & 8 \\
\hline 8. Golgunda & 8.8 & 7.6 & 42.2 & 20.4 & 58 & 2.1 & 0.99 & 22 & 201 & 8 \\
\hline 9. Village-2 & 10.2 & 9.1 & 52.6 & 22.2 & 118 & 0.9 & 1.36 & 0 & 168 & 11 \\
\hline 10. VSSUT & 108.6 & 10.1 & 58.6 & 23.0 & 129 & 4.6 & 0.91 & 18 & 205 & 16 \\
\hline 11. MCL Office & 242.6 & 11.6 & 61.6 & 16.8 & 68 & 4.2 & 1.06 & 41 & 99 & 11 \\
\hline 12. HINDALCO & 99.6 & 18.2 & 80.1 & 18.8 & 52 & 4.4 & 2.6 & 32 & 106 & 12 \\
\hline 13. Blue Fox Industry & 118.2 & 10.8 & 27.2 & 16.1 & 88 & 0.9 & 0.7 & 16 & 96 & 14 \\
\hline 14. Village-3 & 98.2 & 10.9 & 52.6 & 18.2 & 128 & 1.1 & 1.88 & 28 & 111 & 10 \\
\hline
\end{tabular}




\begin{tabular}{|l|l|l|l|l|l|l|l|l|l|l|}
\hline 15. Remed & 212.2 & 14.6 & 61.2 & 19.2 & 108 & 1.6 & 1.96 & 4 & 208 & 9 \\
\hline 16. Bareipali & 188.6 & 5.6 & 52.2 & 22.4 & 180 & 2.1 & 1.11 & 26 & 211 & 11 \\
\hline 17. Airport & 99.6 & 9.9 & 33.3 & 24.1 & 99 & 3.6 & 1.1 & 40 & 68 & 17 \\
\hline 18. Village-4 & 252.6 & 11.7 & 18.6 & 9.1 & 108 & 1.1 & 1.02 & 41 & 206 & 18 \\
\hline $\begin{array}{l}\text { 19. Government. } \\
\text { Hospital }\end{array}$ & 411.6 & 118.2 & 7.2 & 11.1 & 142 & 1.1 & 0.7 & 47 & 211 & 14 \\
\hline 20. Tangerpali & 512.6 & 14.2 & 8.1 & 9.2 & 102 & 0.9 & 0.98 & 18 & 168 & 11 \\
\hline 21. GM university & 99.6 & 7.2 & 18.6 & 16.4 & 96 & 0.8 & 0.96 & 35 & 252 & 10 \\
\hline 22. Gopalmal & 128.6 & 6.4 & 22.6 & 8.8 & 180 & 2.4 & 0.9 & 42 & 92 & 9 \\
\hline 23. Danipali & 168.2 & 5.8 & 6.6 & 4.5 & 176 & 2.6 & 0.7 & 47 & 88 & 14 \\
\hline 24. Durgapali & 381.5 & 4.8 & 16.4 & 5.5 & 96 & 0.5 & 0.68 & 52 & 191 & 16 \\
\hline 25. Budharaja & 377.2 & 6.8 & 9.1 & 4.2 & 92 & 0.6 & 1.6 & 18 & 111 & 14 \\
\hline 26. New Township & 199.6 & 8.8 & 11.1 & 6.4 & 191 & 1.2 & 2.1 & 22 & 29 & 11 \\
\hline 27. Modipara & 198.2 & 10.2 & 18.2 & 8.8 & 106 & 1.1 & 1.8 & 46 & 69 & 12 \\
\hline 28. Police Hospital & 311.2 & 10.9 & 4.6 & 4.6 & 108 & 1.0 & 1.1 & 51 & 120 & 9 \\
\hline 29. Daleipara & 306.6 & 11.1 & 8.9 & 3.8 & 99 & 1.6 & 0.9 & 16 & 142 & 8 \\
\hline 30. Brooxhill & 288.7 & 10.6 & 10.6 & 6.4 & 96 & 2.1 & 1.1 & 18 & 166 & 11 \\
\hline 31. Charbhati & 211.2 & 12.1 & 11.9 & 6.2 & 88 & 3.1 & 1.2 & 19 & 188 & 10 \\
\hline 32. Binakhandi & 102.7 & 10.2 & 20.1 & 8.8 & 64 & 1.6 & 0.08 & 14 & 200 & 13 \\
\hline 33. Maneswar & 127.6 & 10.1 & 29.4 & 9.2 & 78 & 1.8 & 1.01 & 16 & 99 & 14 \\
\hline
\end{tabular}

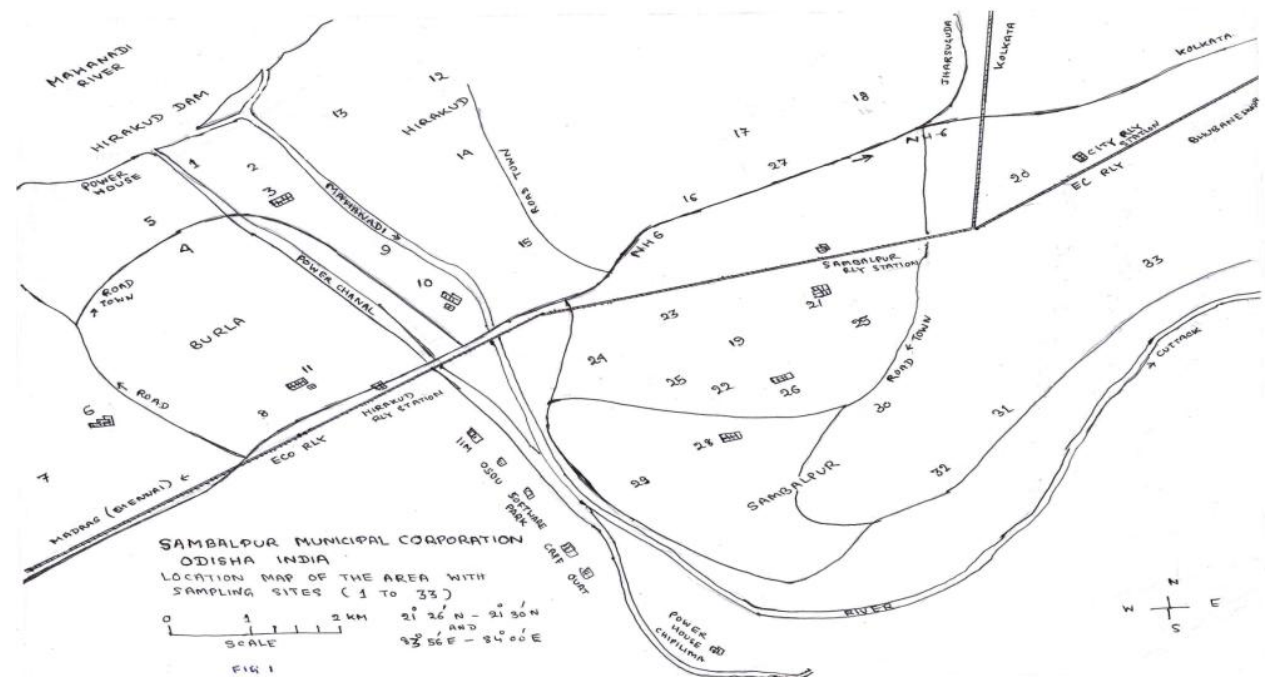

Figure 1: Sambalpur Municipal Corporation, Location map of the area with sampling sites

\section{RESULTS AND DISCUSSION}

The physic-chemical parameters of water samples collected from the underground water as given in the Table 1.A and Table 1.B. It is observed by $\mathrm{pH}$ measurement that the water samples obtained from the bore wells are slightly basic in nature, which is more than $7 \mathrm{pH}$, but within the permissible limit for drinking as per WHO. But water of 6 bore wells have satisfied the permissible limit as per European standard where as TDS of water of 7 bore wells are unsuitable for drinking as prescribed by WHO. The temperature variation is found to be $30^{\circ} \mathrm{C}$ to $34^{\circ} \mathrm{C}$ during pre-monsoon period. These differences depend upon the rock type and depth of the wells. The hardness value of water taken from all the wells are quite less than the levels specified for drinking (limit of WHO in 500ppm) and mostly in classified as hard (Twort et al, 1974). The total alkalinity of water is high except 5 bore wells. The hardness and alkalinity of water of these bore wells are mentioned in the test probably due to the content of ground water with minerals of alkali and alkaline earth metals. Although the lower DO values, less than $4 \mathrm{ppm}$ indicate water pollution but usually underground water, in general is less contaminated. Except 5 bore wells, the DO levels in the rest sources are below 4ppm and it is obvious in case of ground water.

Generally ground water also exceeds the concentrations of $\mathrm{CO}_{2}$ level less than surface water. In this study at some bore wells, the amount of $\mathrm{CO}_{2}$ found to be very high, that is about $65 \mathrm{ppm}$ which exceeds the desired limit. The COD value of drinking water should not exceed 10ppm, which is 
an indicator of total amount of oxidisable organic and bio-organic matters present in water. But it has been observed that in the water of all the bore wells, this parameter has exceed the limit and in some wells COD is more than ten folds of the maximum permissible limit (WHO), which is alarming. The $\mathrm{Mg}^{++}$is very less in compare to $\mathrm{Na}^{+}, \mathrm{K}^{+}, \mathrm{Ca}^{++}$in most of the cases, because these ground water are mostly associated with granite rocks. However, in some case $\mathrm{Ca}^{++}$concentration is high. The amount of Chlorine in water samples is below the limit.
Similarly $\mathrm{SO}_{4}{ }^{2-}$ (sulphate) ion is less than the limiting value. The Fluoride concentration in some water samples is more than the permissible limit. As these bore wells are meant for the collection of drinking water, hence primarily the water quality has been judged from the point of view. From the present study it is found that except some bore wells when COD value and fluoride value are high, the water quality of other bore wells are good and suitable for drinking purpose.

Table 2: Variation of physico-chemical parameters with rock types.

\begin{tabular}{|c|c|c|c|c|c|}
\hline $\begin{array}{l}\text { Sl. } \\
\text { No. }\end{array}$ & Parameter & Description & Amphibolite & $\begin{array}{l}\text { Medium } \\
\text { Grained } \\
\text { Granodiorite }\end{array}$ & $\begin{array}{l}\text { Porphyritic } \\
\text { Granodiorite }\end{array}$ \\
\hline 1 & $\mathrm{pH}$ & $\begin{array}{l}\text { Potential of Hydrogen, in } \\
\text { moles/L }\end{array}$ & 7.5 & 7.9 & 7.88 \\
\hline 2 & $\mathrm{EC}$ & $\begin{array}{l}\text { Electrical Conductivity, in } \mu \text { mho } \\
\text { /cm }\end{array}$ & 1027.2 & 612.6 & 888.42 \\
\hline 3 & Temp & Temperature, in ${ }^{\circ} \mathrm{C}$ & 32.2 & 33.6 & 33.8 \\
\hline 4 & TDS & Total Dissolved Solids, in ppm & 602 & 302 & 466 \\
\hline 5 & TH & Total Hardness, in ppm & 263 & 261 & 271 \\
\hline 6 & TA & Total Alkalinity, $\mathrm{CaCO}_{3}$ in ppm & 111 & 121 & 141 \\
\hline 7 & $\mathrm{Ca}^{2+}$ & Calcium, in ppm & 11.30 & 22.4 & 121.6 \\
\hline 8 & $\mathrm{Mg}^{2+}$ & Magnesium, in ppm & 7.21 & 6.66 & 8.01 \\
\hline 9 & $\mathrm{Na}^{+}$ & Sodium, in ppm & 28.42 & 36.11 & 49.23 \\
\hline 10 & $\mathrm{~K}^{+}$ & Potassium, in ppm & 28.4 & 19.91 & 26.23 \\
\hline 11 & $\mathrm{Cl}^{-}$ & Chloride, in ppm & 88.2 & 51.2 & 83.11 \\
\hline 12 & $\mathrm{SO}_{4}{ }^{2-}$ & Sulphate, in ppm & 5.12 & 2.1 & 2.26 \\
\hline 13 & $\mathrm{Fe}^{-}$ & Iron, in $\mathrm{ppm}$ & 2.2 & 1.1 & 1.02 \\
\hline 14 & $\mathrm{CO}_{3}{ }^{2-}$ & Carbonate, in ppm & 44.6 & 19.2 & 28.60 \\
\hline 15 & $\mathrm{HCO}_{3}^{-}$ & Bicarbolate, in ppm & 88.4 & 99.2 & 95.22 \\
\hline 16 & $\mathrm{DO}$ & Dissolved Oxygen, $\mathrm{mg} / \mathrm{L}$ & 3.71 & 3.88 & 3.93 \\
\hline 17 & $\mathrm{CO}_{2}$ & Free $\mathrm{CO}_{2}$, in $\mathrm{ppm}$ & 14.67 & 24.33 & 27.08 \\
\hline 18 & COD & $\begin{array}{l}\text { Chemical Oxygen Demand, in } \\
\text { ppm }\end{array}$ & 24.11 & 23.11 & 28.61 \\
\hline
\end{tabular}

Although the fluoride concentrations vary considerably, the samples in localities nearer to the amphibolites exposure have high fluoride contents beyond desirable level for drinking [5]. Since fluoride content in ground water commonly depends upon rock type from which they originate, the content of water, with the amphibolites and granite containing biotite, apatite, etc has resulted in higher concentration of fluoride in some areas. These minerals may also contain fluoride by replacement of hydroxide ion $\left(\mathrm{OH}^{-}\right)$[6]. During weathering and circulation of water in rocks and soils, fluoride is leached out and gets dissolved in the ground water. From the study of fluoride concentration the areas around Budharaja, Ainthapali, Hirakud, village 3 Remed, Gopalpali , Burla, village 2 can be recognized as high fluoride zones(>1ppm). The sodium $(\mathrm{Na}+)$ absorption reaction (SAR) of 0.18 to 5.38 indicates that the ground water of the areas to be good for irrigation (U.S.D.A 1984). However sodium percentage values vary widely and except a few samples, the ground water is suitable for irrigation purpose [7].

From the lithology study these dominant rock types are amphibolites, medium granted granodiorite and porphyritic granodiorite.The variation of the physico-chemical parameters is presented in Table 2.

Petrographic analysis reveals considerable extent of alteration of the granodutites. There has been extensive sericitization of the feldspar grains. Due to weathering feldspathic rocks are also kaolinosed 
with the development of clayey sand and development of aquifer conditions at shallower depths up to 15 meter.

The quality of ground water is dependent on the predominant rock types and there weathered products, the later being the host for most of the ground water in this area. The investigation involving geological, hydro-geological, hydrochemical and statistical techniques have aided in accessing the relations of lithology with ground water quality.

The concentration of cataions and anaions of ground water of this study area is different rocks is in the following order;

a. Amphibolite:

\section{CONCLUSION}

This is concluded from the investigation of the ground water quality with respect to physical and chemical parameters that the water is fit for drinking purposes. In some areas though concentration of fluoride is higher, still it is not harmful at present as dental fluorosis is not found in area of study.In some areas the hardness of water is high, but it is safe for drinking; only it corrodes the pipes and taps as a result they do not last long due to scale formation. The public health department should investigate the quality of water from time to time and give suggestions if needed in near future. The water is also suitable for agriculture.

\section{ACKNOWLEDGEMENTS}

The authors are highly thankful to Prof.(Retd) Dr. B.K.Sinha, Department of Environmental Science, Sambalpur University, Mr. A.K.Behera, Senior Scientist, State Pollution Control Board, Bhubaneswar, Odisha, and Prof. R.B.Panda, Department of Chemistry, VSS University of Technology, Burla, for the laboratory facilities and their suggestions to carry out this research paper.

\section{REFERENCES}

[1]. A. Naik and P.K. Naik, Petrography and Geochemistry of Amphibolites of Sambalpur, Orissa, Indian Journal of Earth Science, 1995, 22(3)90-98.

[2]. E. Brown, M.W. Shovgestei and M. J. Fishman, 1974, Methods for collection and analysis of water samples for dissolved minerals and gases, U.S. Dept of Interior, Book No-5.

[3]. APHA 2008(Revised) Standard method for Examination of water and waste water, American Public Health Association, Washington, D.C.

[4]. R.K. Trivedi and P.K. Goel, Chemical and biological methods for water pollution
$\mathrm{K}^{+}>\mathrm{Na}^{+}>\mathrm{Ca}^{2+}>\mathrm{Mg}^{2+}$

$\mathrm{HCO}_{3}{ }^{-}>\mathrm{Cl}^{-}>\mathrm{CO}_{3}{ }^{2-}>\mathrm{SO}_{4}{ }^{2-}$

b. Medium grained granodiorite:

$\mathrm{Na}^{+}>\mathrm{Ca}^{2+}>\mathrm{K}^{+}>\mathrm{Mg}^{2+}$

$\mathrm{HCO}_{3}{ }^{-}>\mathrm{Cl}^{-}>\mathrm{CO}_{3}{ }^{2-}>\mathrm{SO}_{4}{ }^{2-}$

c. Porphyritic granodiorite:

$\mathrm{Ca}^{2+}>\mathrm{Na}^{+}>\mathrm{K}^{+}>\mathrm{Mg}^{2+}$

$\mathrm{HCO}_{3}{ }^{-}>\mathrm{Cl}^{-}>\mathrm{CO}_{3}{ }^{2-}>\mathrm{SO}_{4}{ }^{2-}$

The order of the above concentration for anions has a significant variation. In case of cations, except a few cases the quality of water can be generally concluded to be good for irrigation also.

studies, Envirtl.l Pub., Kard, India, 1-215, (1984).

[5]. ISI, 1989, Indian Standard Specification for Drinking Water, IS: 10500.

[6]. J.D. Hem, Study and interpretation of chemical characteristics of natural water (5th Edition), USGS Water Sampling (1999)

[7]. X.L.V. Wilco, Classification and use irrigation waters, U.S Dept Agriculture, Wasington D.C. (1955) 